malignancy. infect Control. 1987;8:71-75.

23. Rhame FS. Nosocomial aspergillosis: how much protection for which patients? Infect Control Hosp Epidemiol. 1989;10:296-298.

24. Sherertz RJ, Belani A, Kramer BS, et al. Impact of air filtration on nosocomial aspergillus infections. Unique risk of bone marrow transplant recipients. Am J Med 1987;83:709-718.

25. Rogers TR. Prevention of infection in neutropenic bone marrow transplant patients. Antibiot Chemother 1985;33:90-113.

26. Iwen PC, Davis JC, Winfield BA. An assessment of air quality monitoring following failure of a protective environment to prevent invasive aspergillosis in neutropenic patients during major construction. Presented at the 92nd General Meeting of the American Society for Microbiology; May 26-30, 1992: New Orleans, La.

27. Woods GL, Davis JC, Vaughan WP. Failure of the sterile airflow component of a protective environment detected by demonstration of Chaetomium species colonization of four consecutive immunosuppressed occupants. Infect Control Hosp Epidemiol. 1988;9:451-456.

28. Khardori N. Host-parasite interaction in fungal infections. Eur $J$ Clin Microbiol Infect Dis. 1989:8:331-351.

29. Rhame FS, Streifel AJ, Kersey JH Jr, McGlave PB. Extrinsic risk factors for pneumonia in the patient at high risk of infection. Am JMed. 1984; 76(5A):42-52.

30. Navarro E, Lecciones J, Witebsky $\mathbf{F}$, et al. Invasive aspergillosis developing during empirical antifungal therapy. Presented at the 90th Annual Meeting of the American Society for Microbiology; May 13-17, 1990: Anaheim, Calii.

31. Rippon JW. Medical Mycology The Rzthogenic Fungi and the Rzthogenic Actinomycetes. 3rd ed. Philadelphia, Pa: W.B. Saunders Co; 1988.

32. Shpilberg 0, Douer D, Goldschmied-Reouven A, et al. Invasive aspergillosis in neutropenic patients with hematological disorders. Leukemia Lymphoma. 1991;4:257-262.
33. Fischler D, Stoler M, Nunez C, Hall G. Identification of Aspergillus sp: a comparison of culture, cytology, and surgical pathology results. Presented at the 92nd General Meeting of the American Society for Microbiology; May 26-30, 1992: New Orleans, La.

34. Talbot GH, Huang A, Provencher M. Invasive aspergillus rhinosinusitis in patients with acute leukemia. Rev Infect Dis. 1991;13:219-232.

35. Allo MD, Miller J, Townsend T, Tan C. Primary cutaneous aspergillosis associated with Hickman intravenous catheters. N Engl J Med. 1987;317:1105-1108.

36. Solomon WR, Burge HP Boise JR Airbom Aspergillus fumigatus levels outside and within a large clinical center. /Allergy Clin Immunol. 1978;62:56-60.

37. Walsh TJ, Lee J, Lecciones J, et al. Empiric therapy with amphotericin B in febrile granulocytopenic patients. Rev infect Dis. 1991;13:496-503.

38. Karp JE, Merz WG, Char-ache 1? Response to empiric amphotericin B during antileukemic therapy-induced granulocytopenia. Rev Infect Dis. 1991;13:592-599.

39. Denning DW, Stevens DA. Antifungal and surgical treatment of invasive aspergillosis: review of 2,121 published cases. Rev Infect Dis. 1990;12:1147-1201.

40. Kurup VP, Kumar A. Immunodiagnosis of aspergillosis. Clin Microbiol Rev. 1991;4:439-456.

41. Vose JM, Bierman PJ, Kessinger A, et al. The use of recombinant human granulocyte-macrophage colony stimulating factor for the treatment of delayed engraftment following high dose therapy and autologous hematopoietic stem cell transplantation for lymphoid malignancies. Bane Marrow Transplant. 1991;7:139143.

42. Denning DW, Stepan DE, Blume KG, Stevens DA Control of invasive pulmonary aspergillosis with oral intraconazole in a bone marrow transplant patient. J Infect. 1992;24:74-79.

\section{Pagination Problems in New Textbook}

If you ordered the second edition of Dr. Richard Wenzel's text Prevention and Control of Nosocomial Infections prior to publication and received your book in January 1993, you may wish to check your copy. The publisher shipped a number of volumes before discovering that some had pages missing or out of order, particularly within the first 128 pages.

If you find that your book is defective, you may phone Williams and Wilkins's customer service department at 1-800-638-0672 to arrange for replacement. If you have not yet ordered Dr. Wenzel's book, you may do so at the same phone number.

A review of Dr. Wenzel's text will appear in a future issue of Infection Control and Hospital Epidemiology. 